\title{
FENOMENA SELF EFFICACY TERHADAP PARTISIPASI MASYARAKAT PADA PILKADA DI KABUPATEN PASAMAN 2015
}

\author{
Purwo Andri Prabowo \\ Jurusan Ilmu Politik, Fisip, Universitas Andalas \\ Email: andriprabowo001@gmail.com
}

\begin{abstract}
Abstrak
Di Kabupaten Pasaman, masyarakat multi etnis mendiami kawasan Kabupaten Pasaman dari waktu yang cukup lama dikarenakan faktor sejarah masyarakat yang mendatangi Kabupaten Pasaman dari berbagai daerah. Masyarakat di Kabupaten Pasaman kebanyakan didominasi oleh suku Mandailing dan suku Minang. Pelaksanaan Pilkada 2015 di Kabupaten Pasaman menjadi catatan tersendiri ketika Self Efficacy menjadi pengaruh atau tidaknya pada masyarakat dalam menentukan pilihan politik mereka. Perbedaan etnis yang dimiliki oleh kedua pasangan calon, Benny Utama dan Yusuf Lubis, mempengaruhi partisipasi masyarakat pada pelaksanaan Pilkada 2015. Penelitian ini bertujuan untuk Menjelaskan Faktor Self Efficacy pada masyarakat Pasaman yang mengakibatkan menurunnya partisipasi masyarakat dalam Pilkada di Kabupaten Pasaman 2015. Metode pada penelitian ini menggunakan kualitatif dengan tipe studi kasus, Teknik pemilihan informan Snow Ball, Sementara teknik keabsahan data yang digunakan adalah triangulasi sumber. Hasil dari penelitian ini menunjukan bahwa ada 2 faktor yang mempengaruhi partisipasi masyarakat pada Pilkada 2015 di Kabupaten Pasaman yaitu faktor internal dan faktor eksternal. Faktor internal yang mempengaruhi penurunan partisipasi masyarakat adalah anggapan masyarakat yang tidak ada gunanya untuk ikut berpartisipasi dalam Pilkada 2015 di Kabupaten Pasaman. Nilai-nilai yang telah ditanamkan pada diri masyarakat tersebut menjadi budaya secara turun temurun. Sedangkan faktor eksternal bahwa hilangnya kepercayaan masyarakat terhadap kinerja pemerintah sehingga masyarakat trauma untuk ikut berpartisipasi pada Pilkada 2015 di Kabupaten Pasaman.
\end{abstract}

Kata Kunci: Multietnis ; Pilkada ; Efikasi Politik ; Etnis ; Sawahlunto

\begin{abstract}
In Pasaman Regency, multi-ethnic communities inhabit the Pasaman Regency area for quite a long time due to the historical factor of the people who came to Pasaman Regency from various regions. Communities in Pasaman Regency are mostly dominated by Mandailing and Minang tribes. The implementation of the 2015 elections in Pasaman Regency is a separate note when Self Efficacy is the influence or not on the community in determining their political choices. The ethnic differences possessed by the two candidate pairs, Benny Utama and Yusuf Lubis, influenced community participation in the implementation of the 2015 elections. This study aimed to explain the Self Efficacy Factor in the Pasaman community which resulted in decreased community participation in the elections in Pasaman District 2015. The method in this study using qualitative with the type of case study, Snow Ball informant selection technique, while the data validity technique used is source triangulation. The results of this study indicate that there are 2 factors that influence community participation in the 2015 elections in Pasaman Regency, namely internal factors and external factors. Internal factors that influence the decline in community participation are the people's assumption that there is no point in participating in the 2015 elections in Pasaman Regency. The values that have been instilled in the community become a hereditary culture. While external factors are that the loss of public trust in government performance so that people are traumatized to participate in the 2015 elections in Pasaman Regency.
\end{abstract}

Keywords: Multi Ethnic ; Election ; Political Efficacy ; Ethnicity ; Self Efficacy ; Pasaman 


\section{PENDAHULUAN}

Self efficacy adalah mengacu pada keyakinan individu mengenai kemampuannya untuk memobilisasi motivasi, sumber daya kognitif, dan tindakan yang diperlukan agar berhasil melaksanakan tugas dalam konteks tertentu. ${ }^{1}$ Contohnya pada proses pemilihan kepala daerah, efikasi diri sangat diperlukan bagi orang yang ikut serta dalam kontestasi pemilihan kepala daerah, pasalnya keyakinan diri untuk dapat mempengaruhi masyarakat agar masyarakat tersebut meyakini visi misi dengan potensi yang dimiliki. Individu yang mempunyai ekspektasi diri yang rendah akan berpengaruh terhadap perilaku yang rendah, tetapi ketika ekspektasi diri nya tinggi maka hasil akhirnya optimal dan memuaskan. ${ }^{2}$ Keyakinan ${ }^{3}$ tersebut yang mengacu pada mental dan kesiapan seseorang untuk dapat berhadapan dengan individu atau kelompok lainnya.

Menurut Huntington dan Nelson partisipasi dalam pemilihan umum merupakan salah satu bentuk partisipasi politik warga negara. Partisipasi politik adalah aktivitas warga yang dimaksudkan untuk mempengaruhi pengambilan keputusan yang dilakukan oleh pemerintah Partisipasi politik dapat bersifat individu ataupun kelompok, terorganisir ataupun spontan, mapan ataupun sporadis, dengan cara damai ataupun kekerasan. Penurunan tingkat partisipasi warga dalam setiap pemilihan umum dikarenakan berbagai faktor baik yang bersifat eksternal maupun internal. Faktor eksternal terkait dengan situasi atau lingkungan politik yang dibangun oleh negara. Sedangkan, faktor internal adalah yang ada dalam diri individu, yang mengarahkan keinginan dan kebutuhan seseorang untuk mengambil peran dalam proses maupun kegiatan politik. Kesadaran mengenai pentingnya peran warga dalam melaksanakan hak dan kewajibannya sebagai warga Negara tidak hanya pada taraf pengetahuan (kognitif) melainkan harus tumbuh menjadi sebuah keyakinan bahwa dirinya dapat mempengaruhi atau berdampak pada proses politik Negaranya. Keyakinan bahwa akan lebih bermanfaat jika dirinya turut melakukan tugas kewarganegaraannya. Keyakinan ini disebut political efficacy (efikasi politik).

Istilah efikasi politik populer digunakan sebagai "barometer sistem demokrasi", selain sering kali juga dianggap sebagai prediktor dari perilaku politik. Efikasi politik secara tradisional digunakan untuk menilai alasan di balik kecenderungan relatif seseorang untuk berpartisipasi dalam kehidupan politik. Tanpa rasa efikasi politik internal, warga pemilih kemungkinan akan menjadi apatis, acuh tak acuh terhadap proses politik yang terjadi. Keengganan itu kemudian akan membuat warga memilih menjadi golongan putih. Partisipasi seseorang dalam bidang sosial dan politik merupakan bentuk tingkah laku sosial yang dipengaruhi oleh nilai-nilai yang dianutnya. Nilai digunakan

\footnotetext{
${ }^{1}$ Isnaini Oktaverina dan H. Fuad Nashori. "Efektivitas Pelatihan Efikasi diri dalam meningkatkan motivasi belajar". Talenta Vol.1(1) Hlm. 1-14.

2 Asep Saepudin, Dkk. "Efektivitas Pelatihan Dan Efikasi Diri". Jurnal Mimbar. Vol. 31(1) Hlm. 93-102

${ }^{3}$ Keyakinan tersebut diartikan sebagai kepercayaan diri seseorang, agar dapat memobilisasi motivasi individu atau kelompok.
} 
untuk merepresentasikan tujuan-tujuan secara mental dan disampaikan melalui interaksi sosial. Adapun personal values (nilai personal) adalah konstruk motivasional yang ada dalam diri seseorang dan dapat mempengaruhi tingkah laku sosial orang tersebut terhadap orang-orang disekitarnya. ${ }^{4}$

Pada demokrasi ada sistem pemilihan umum yang ada di Indonesia. ${ }^{5}$ Pemilihan umum merupakan salah satu usaha untuk mempengaruhi rakyat secara persuasif (tidak memaksa) dengan melakukan kegiatan retorika, hubungan publik, komunikasi massa, lobi dan lain-lain kegiatan. Meskipun agitasi dan propaganda di negara demokrasi sangat dikecam termasuk Indonesia sendiri, namun dalam kampanye pemilihan umum, teknik agitasi dan teknik propaganda banyak juga dipakai oleh para kandidat atau politikus ketika melakukan komunikator politik.

Menariknya Self Efficacy sangat berpengaruh pada saat kampanye dilakukan, hal ini disebabkan karena pada saat kampanye dilaksanakan terdapat kontak sosial antara individu dengan individu, individu dengan kelompok maupun antar kelompok dengan kelompok lainnya. Menurut Riedel dan sullivan ada dua faktor efikasi diri terhadap politik yaitu ${ }^{6}$; (1)faktor internal adalah keyakinan seseorang bahwa dampak dari partisipasi tidak akan mempengaruhi dirinya apapun yang terjadi dalam kehidupan politik,contohnya, pada pemilihan umum dilaksanakan, anggapan dari masyarakat bahwa siapapun pemimpin yang terpilih tidak akan mempengaruhi kehidupannya; (2)Faktor Eksternal adalah anggapan masyarakat terhadap kinerja dari lembaga-lembaga pemerintahan, contohnya, anggapan dari masyarakat terhadap pemerintahan yang melakukan tindakan kriminal seperti korupsi, sehingga masyarakat beranggapan hanya membuang-buang waktu saat ikut berpartisipasi dalam pemilihan umum.

Keadaan di wilayah Kabupaten Pasaman yang beragam suku dan budaya merupakan kekayaan dari wilayah menuju transisi. Penduduk yang masih kental dengan adat dan istiadat menjadikan hubungan yang sangat erat antara satu kaum dengan kaum lainnya, tetapi hanya dengan suku dan budaya yang sama. Berbeda dengan sekelompok masyarakat yang tidak satu suku dan budaya menjadikan perbedaan suku dan budaya ini rentan terjadinya konflik.

keadaan wilayah di Pasaman yang mempunyai beragama suku dan budaya sangat berpengaruh pada saat dilaksanakannya Pilkada 2015 di Kabupaten Pasaman. Masyarakat yang memiliki suku yang sama dengan pasangan calon yang akan naik lebih memprioritaskan pasangan calon yang memiliki suku yang sama dengan masyarakat tersebut, hal itu lumrah untuk dilakukan, tetapi masyarakat tersebut tidak melihat kinerja dan rekam jejak dari pasangan calon yang akan naik. Mereka tidak mementingkan bagaimana kinerjanya dan hanya terfokus pada suku dan budaya yang sama.

\footnotetext{
${ }^{4}$ Elis Anisah Fitriah. "personal Value and internal political efficacy terhadap partisipasi Politik Pemilih Pemula”. Jurnal Studi, Hlm.244-254

${ }^{5}$ Miriam Budiardjo "Dasar-Dasar Ilmu Politik”. Jakarta: Gramedia. Hlm.106

${ }^{6}$ Op.Cit., Elis Anisah Fitriah. "personal Value and internal political efficacy terhadap partisipasi Politik Pemilih Pemula”. Jurnal Studi, Hlm.244-254
} 
Ketidakyakinan masyarakat akan pasangan calon yang akan naik menjadi Bupati Pasaman bisa dilihat pada saat kampanye dilakukan. Tim sukses dari kedua pasangan calon kebanyakan kampanye dilakukan pada daerahnya, maksudnya pasangan calon yang akan naik melaksanakan kampanye pada masyarakat yang memiliki suku dan budaya yang sama dengan pasangan calon, dan banyak wilayah yang tidak dikunjungi oleh pasangan calon. Sehingga imbas dari kampanye yang dilakukan pasangan calon.

Pada saat Pilkada 2015 di Kabupaten Pasaman di 12 Kecamatan yaitu, Beberapa wilayah atau kelompok masyarakat, rata-rata penduduknya tidak mau mengeluarkan suara (GOLPUT) dalam pelaksanaan Pilkada. Peneliti melihat dari tahun ke tahun Masyarakat di Kabupaten Pasaman selalu mengalami kemunduran atau pengurangan jumlah suara dari sensus jumlah masyarakat yang ada di Kabupaten Pasaman. ${ }^{7}$

Peneliti berasumsi bahwa ada faktor yang menyebabkan penurunan partisipasi politik masyarakat Kabupaten Pasaman dalam Pilkada 2015, dikarenakan oleh Self Efficacy yang rendah pada masyarakat Kabupaten Pasaman itu sendiri. kemudian terjadi akibat 2 faktor eksternal dan faktor internal. Faktor eksternal adalah keyakinan dari masyarakat Kabupaten Pasaman yang menganggap bahwa pasangan calon hanya mempertahankan etnis yang sama dan mencari jabatan saja.

Secara keseluruhan, ada yang menjadi pilihan peneliti yang dianggap cukup relevan untuk diajukan sebagai rujukan bagi penulisan penelitian ini adapun penelitian terdahulu tersebut diteliti oleh Elis Anisah Fitriah 2014, dengan judul penelitian Personal Values dan Internal Political Efficacy Terhadap Partisipasi Politik Mahasiswa Pemilih Pemula. Metode yang digunakan dalam penelitian ini adalah metode kuantitatif dengan cara menyebar kuesioner, melakukan wawancara dan Observasi. Penelitian yang dilakukan dapat disimpulkan bahwa penelitian ini bertujuan untuk memperoleh gambaran bagaimana kontribusi relatif Personal Values dan efikasi Politik Internal terhadap partisipasi politik pemilih pemula. ${ }^{8}$ Teori yang digunakan dalam penelitian adalah Self Efficacy dan Political Efficacy.

Penelitian ini Mengungkapkan bahwa Partisipasi mahasiswa yang disebabkan oleh faktor efikasi diri yang belum tahu sepenuhnya tentang pemilu, sehingga peran KPU sebagai aktor utama yang dapat mempengaruhi mahasiswa tersebut. Penelitian ini sangat baik untuk dijadikan rujukan sebagai penelitian terdahulu, tetapi dalam penelitian ini terkait pada pemilih pemula yang mempengaruhi partisipasi mahasiswa dalam menyajikan penelitiannya, berbeda dengan penelitian peneliti yang meneliti dimulai dari keadaan wilayah, kesukuan, sehingga dapat mempengaruhi partisipasi masyarakat pada Pilkada.

Hasil penelitian ini menunjukkan bahwa ada pengaruh yang signifikan antara Personal Values dan Internal Political Efficacy secara bersama-sama terhadap partisipasi politik. Namun secara parsial, ditunjukkan oleh Internal Political Efficacy terhadap partisipasi politik menunjukkan hubungan yang signifikan. Political Efficacy sangat ditentukan oleh proses sosialisasi politik yang diperoleh oleh individu yang terkait dengan tingkatan pendidikan maupun

\footnotetext{
${ }^{7}$ Data KPU Kabupaten Pasaman 2010-2015

${ }^{8}$ Op.Cit., Elis Anisa Fitriah, Personal Values dan Internal dan Internal Political Efficacy Terhadap Partisipasi Politik Mahasiswa Pemilih Pemula. Skripsi tahun 2014
} 
informasi yang diperoleh mengenai dinamika kehidupan politik yang terjadi sebagai konteks sosial dimana orang hidup didalamnya.

Selanjutnya, menurut Sharifah Sofia Wan Ahmad 2018, tentang Pengaruh Media Pada Efikasi Mahasiswa Terhadap Partisipasi Dalam Percakapan Politik. Metode yang digunakan dalam penelitian ini adalah Kuantitatif dengan tipe Eksploratif dan membagikan kuesioner. Penelitian ini bertujuan untuk melihat bagaimana pengaruh media terhadap perilaku efikasi mahasiswa terhadap partisipasi dalam percakapan politik, khususnya hubungan antara penggunaan media, pengetahuan tentang isu-isu, dominasi politik dan efikasi yang dirasakan dalam berpartisipasi dalam percakapan politik ${ }^{9}$.

Hasil penelitian ini menunjukkan bahwa mayoritas responden membaca surat kabar online dan media paling populer untuk mendapatkan informasi tentang isu-isu nasional atau itu majalah. Hasil penelitian juga menunjukkan bahwa efikasi mahasiswa cukup dominan dalam percakapan politik. Penelitian ini telah menunjukkan bahwa ada korelasi positif antara kesepakatan tentang isu-isu politik dan partisipasi politik secara online.

Selanjutnya menurut Lubne Zaheer 2016, yang berjudul tentang Pengaruh menonton Talk Show Politik Terhadap Efikasi Politik dan Partisipasi Politik. Metode yang digunakan dalam penelitian ini adalah Kualitatif dengan cara membagikan kuesioner. Penelitian ini bertujuan untuk mengetahui hubungan antara Talk Show Politik menunjukkan paparan dengan efikasi politik dan partisipasi politik ${ }^{10}$.

Hasil penelitian ini menunjukkan temuan bahwa dugaan politik konsumsi talk show memiliki hubungan langsung dengan efikasi politik dan partisipasi politik. Melihat talk show politik tidak mempengaruhi tingkat efikasi politik dan partisipasi politik. Ada unsur lain yang dapat mempengaruhi efikasi politik dan partisipasi politik, misalnya, berbagai demografi yaitu umur, jenis kelamin, Pendidikan dan pendapatan. Meskipun usia dan Pendidikan belum ditemukan terkait dengan efikasi politik dan partisipasi politik, namun, jenis kelamin dan pendapatan merupakan faktor yang signifikan.

Selanjutnya menurut Chia-Chou Wang 2018, yang berjudul Disonansi Kognitif dan Perubahan Eksternal Pada Keampuhan Efikasi Politik Mahasiswa Taiwan. Penelitian ini menggunakan metode kualitatif dengan tipe deskriptif, dilakukan dengan cara wawancara dan Observasi. Tujuan dari penelitian ini adalah melihat bagaimana disonansi kognitif terhadap pengaruh luar dan perubahan eksternal pada keampuhan efikasi politik terhadap mahasiswa Taiwan ${ }^{11}$.

Hasil dari penelitian ini menunjukkan bahwa belajar di negara demokrasi dapat memfasilitasi mahasiswa dari negara-negara komunis dalam mempromosikan reformasi politik di masa depan. Kedua, mengusulkan penjelasan baru untuk perubahan efikasi politik eksternal

\footnotetext{
${ }^{9}$ Op.Cit., Sophia Wan Ahmad, Pengaruh Media Pada Efikasi Mahasiswa Terhadap Partisipasi Dalam Percakapan Politik, Skripsi Tahun 2018

${ }^{10}$ Op.Cit., Lubne Zaheer, "Pengaruh Menonton Talk Show Politik Terhadap Efikasi Politik dan Partisipasi Politik", Skripsi Tahun 2016

${ }^{11}$ Op.cit., Chia-Chou Wang "Disonansi Kognitif dan Perubahan Eksternal Terhadap Keampuhan Efikasi Politik Mahasiswa Taiwan”, Skripsi Tahun 2018
} 
atas dasar teori disonansi kognitif. Ketiga, dari semua model pengurangan disonansi kognitif memiliki kekuatan penjelasan mengenai perubahan efikasi politik eksternal antara responden.

\section{Konsep Self Efficacy}

Konsep self efficacy merupakan inti dari social cognitive yang dikemukakan oleh Albert Bandura yang menekankan peran belajar observasional, pengalaman sosial, dan determinisme timbal balik dalam pengembangan kepribadian. Menurut Bandura. self efficacy adalah keyakinan seseorang dalam kemampuannya untuk melakukan suatu bentuk control terhadap fungsi orang itu sendiri dan kejadian dalam lingkungan. Bandura juga menggambarkan self efficacy sebagai penentu bagaimana orang merasa, berpikir, memotivasi diri, dan berperilaku. ${ }^{12}$

Pada hakikatnya efikasi harus dipunyai setiap masyarakat atau orang yang terkait di dalam politik maupun pada setiap orang yang terikat dalam organisasi. Hal ini sering kali kita jumpai pada pemilu dalam bernegara atau dalam organisasi di pemerintahan (Birokrasi). Pada dasar nya pemilu sangat mempengaruhi pada pengaruh efikasi pada tingkat partisipasi masyarakat. ${ }^{13}$

Catellani menemukan bahwa efikasi politik atau rasa berperan dalam bidang politik mempengaruhi aktivitas politik yang dilakukan. Dikalangan mahasiswa sebagai kaum muda, partisipasi politik dipengaruhi oleh orientasi politik yang terdiri dari toleransi politik dan komitmen terhadap nilai-nilai demokrasi dan efikasi politik. Dalam perspektif tradisional, efikasi politik diartikan sebagai persepsi yang dimiliki seseorang tentang dirinya dan kemampuannya untuk mempengaruhi politik pada situasi tertentu. Matulessy menyebutkan bahwa budaya politik tidak hanya merujuk pada orientasi kolektif masyarakat terhadap unsur-unsur dasar dalam sistem politik, yang disebut dengan pendekatan sistem, namun juga terkonsentrasi pada individu, sehingga budaya politik merupakan fokus kajian psikologi atau dengan kata lain berkaitan dengan cara-cara individu melihat sistem politik, seperti apa yang seseorang pikir dan rasakan dengan simbol, Lembaga dan aturan yang ada dalam tatanan politik dan bagaimana pula individu tersebut meresponnya. Efikasi politik terdiri dari dimensi efikasi politik eksternal dan efikasi politik internal menurut Schulz dikutip dari Andi Nurcahya. ${ }^{14}$ Efikasi politik eksternal dan internal.

\footnotetext{
${ }^{12}$ Asmarani, Fadilah. "Hubungan antara efikasi diri dengan culture shock pada mahasiswa alumni non pesantren di Ma’had Sunan Ampel Al-Aly Universitas Islam Negeri Maulana Malik Ibrahim Malang” 2017 hlm. 13

${ }^{13}$ Ibid., Hlm. 15

${ }^{14}$ Andi Nurcahya, et.al "Perbedaan Efikasi Politik Ditinjau dari Kepribadian Ekstraversi Pada Dewan Perwakilan Mahasiswa”, Jurnal Psikologi Teori dan Terapan, Vol.7 (2) 2017, Hlm.77
} 


\section{Faktor Internal Terhadap Self Efficacy Masyarakat}

Efikasi politik internal menurut Sylvester merupakan keyakinan bahwa individu cukup kompeten untuk membuat perubahan dalam keputusan politik. ${ }^{15}$ efikasi politik internal lebih dipengaruhi oleh persepsi yang dimiliki seseorang mengenai kemampuan dirinya. Efikasi politik yang tinggi pada masyarakat selalu dilihat sebagai kebutuhan atas kestabilan demokrasi. Lalu menurut Schulz masyarakat yang secara pasti memiliki efikasi politik akan menjadi pendukung pada sistem demokrasi. Masyarakat harus merasa yakin bahwa mereka mempunyai kekuatan untuk mempengaruhi tindakan dari pemerintah. ${ }^{16}$ Efikasi politik merupakan variabel penting dalam mempengaruhi keterlibatan seseorang di bidang politik ${ }^{17}$

Partisipasi dalam pemilihan umum merupakan salah satu bentuk partisipasi politik warga Negara. Partisipasi politik adalah aktivitas warga yang dimaksudkan untuk mempengaruhi pengambilan keputusan yang dilakukan oleh pemerintah. Partisipasi politik dapat bersifat individu ataupun kelompok, terorganisir ataupun spontan, mapan ataupun sporadis, dengan cara damai ataupun kekerasan.

Tanpa rasa efikasi politik internal, warga pemilih kemungkinan akan menjadi apatis, acuh tak acuh terhadap proses politik yang terjadi. Keengganan itu kemudian akan membuat warga memilih menjadi golongan putih. Partisipasi seseorang dalam bidang sosial dan politik merupakan bentuk tingkah laku sosial yang dipengaruhi oleh nilai-nilai yang dianutnya. Nilai digunakan untuk merepresentasikan tujuan-tujuan secara mental dan disampaikan melalui interaksi sosial. Adapun personal values (nilai personal) adalah konstruk motivasional yang ada dalam diri seseorang dan dapat mempengaruhi tingkah laku sosial orang tersebut terhadap orang-orang disekitarnya. ${ }^{18}$

\section{Faktor Eksternal Terhadap Self Efficacy Masyarakat}

Faktor eksternal terkait dengan situasi atau lingkungan politik yang dibangun oleh Negara. Efikasi politik eksternal lebih dipengaruhi oleh interaksi individu dengan lingkungannya, sedangkan efikasi politik internal lebih dipengaruhi oleh persepsi yang dimiliki seseorang mengenai kemampuan dirinya.

Keyakinan bahwa akan lebih bermanfaat jika dirinya turut melakukan tugas kewarganegaraannya. Keyakinan ini disebut political efficacy (efikasi politik). Istilah efikasi politik populer digunakan sebagai "barometer sistem demokrasi", selain sering kali juga dianggap sebagai prediktor dari perilaku politik. Efikasi politik secara tradisional digunakan untuk menilai alasan di balik kecenderungan relatif seseorang untuk berpartisipasi dalam kehidupan politik.

\footnotetext{
${ }^{15}$ Ibid.,

16 Ibid.,

17 Ibid.,

18 Op.Cit., Elis Anisa Fitriah, Personal Values dan Internal dan Internal Political Efficacy Terhadap Partisipasi Politik Mahasiswa Pemilih Pemula. Skripsi tahun 2014
} 
Catellani menemukan bahwa efikasi politik atau rasa berperan dalam bidang politik mempengaruhi aktivitas politik yang dilakukan. Dikalangan mahasiswa sebagai kaum muda, partisipasi politik dipengaruhi oleh orientasi politik yang terdiri dari toleransi politik dan komitmen terhadap nilai-nilai demokrasi dan efikasi politik. Dalam perspektif tradisional, efikasi politik diartikan sebagai persepsi yang dimiliki seseorang tentang dirinya dan kemampuannya untuk mempengaruhi politik pada situasi tertentu. Matulessy menyebutkan bahwa budaya politik tidak hanya merujuk pada orientasi kolektif masyarakat terhadap unsur-unsur dasar dalam sistem politik, yang disebut dengan pendekatan sistem, namun juga terkonsentrasi pada individu, sehingga budaya politik merupakan fokus kajian psikologi atau dengan kata lain berkaitan dengan cara-cara individu melihat sistem politik, seperti apa yang seseorang pikir dan rasakan dengan simbol, Lembaga dan aturan yang ada dalam tatanan politik dan bagaimana pula individu tersebut meresponnya.

\section{METODE PENELITIAN}

Dalam tradisi penelitian kualitatif, proses penelitian dan ilmu pengetahuan tidak sesederhana apa yang terjadi dalam penelitian kuantitatif, karena sebelum hasil-hasil penelitian kualitatif memberi sumbangan kepada ilmu pengetahuan, tahapan penelitian kualitatif melampaui berbagai tahapan kritis-ilmiah, yang mana seorang peneliti memulai berpikir secara induktif, yaitu menangkap berbagai fakta atau fenomena-fenomena sosial, melalui pengamatan di lapangan kemudian menganalisis nya dan kemudian berupaya melakukan teorisasi berdasarkan apa yang diamati itu. ${ }^{19}$

Jenis penelitian menggunakan metode studi kasus dengan tipe penelitian yang digunakan adalah deskriptif, tipe penelitian deskriptif yaitu data yang terkumpul berbentuk kata-kata, gambar bukan angka-angka. Kalaupun ada angka hanya sebagai penunjang. Data pada penelitian studi kasus bisa diperoleh dari transkrip interview, catatan lapangan, foto dokumen pribadi, pengamatan langsung dan lain-lain. Metode studi kasus telah dijelaskan oleh Robert K.Yin di dalam bukunya bahwasannya studi kasus digunakan sebagai suatu penjelasan komprehensif yang berkaitan dengan berbagai aspek seseorang, suatu kelompok, suatu organisasi, suatu program, atau suatu situasi kemasyarakatan yang diteliti, diupayakan dan ditelaah sedalam mungkin. ${ }^{20}$ Maka dalam penelitian ini, peneliti akan menggunakan metode deskriptif analitis untuk menjelaskan Fenomena Self Efficacy Terhadap Partisipasi Pada Pilkada di Kabupaten Pasaman 2015

\footnotetext{
${ }^{19}$ Burhan Bungin. "Metodologi Penelitian Kualitatif”. Jakarta. PT. Raja Grafindo Persada. 2007. Hlm. 6

${ }^{20}$ Robert K, Yin, “Studi Kasus (Desain dan Metode)”, PT Raja Grafindo Persada, Jakarta, 2003.
} 


\section{HASIL DAN PEMBAHASAN}

\section{Self Efficacy Masyarakat Terhadap Partisipasi Masyarakat di Kabupaten Pasaman Pada Pilkada 2015}

Pemilihan kepala daerah yang biasa disingkat dengan PemiluKada adalah salah satu wujud pelaksanaan dari amanat konstitusi Undang-Undang Republik Indonesia Nomor 10 Tahun 2016 Tentang Perubahan Kedua Atas Undang-Undang Nomor 1 Tahun 2015 Tentang Penetapan Peraturan Pemerintahan Pengganti Undang-Undang Nomor 1 Tahun 2004 Tentang Pemilihan Gubernur, Bupati, dan Walikota menjadi UndangUndang. ${ }^{21}$

Kepala daerah adalah jabatan politik yang bertugas memimpin dan menggerakkan lajunya roda pemerintahan. Pelaksanaan pemilihan kepala daerah melalui perwakilan rakyat di DPRD berdasarkan Undang-Undang Nomor 22 tahun 1999 tentang Pemerintahan Daerah. Koreksi atas sistem hukum pelaksanaan pemilihan kepala daerah secara langsung, yakni, Undang-Undang Nomor 23 tahun 2014 tentang Pemerintahan Daerah yang berbunyi sebagai berikut ${ }^{22}$ :

"Bahwa dalam rangka penyelenggaraan pemerintah daerah sesuai dengan amanat Undang-Undang Dasar Negara Kesatuan Republik Indonesia Tahun 1945, pemerintah daerah, yang mengatur dan mengurus sendiri urusan pemerintahan menurut asas otonomi dan tugas pembantuan, diarahkan untuk mempercepat terwujudnya kesejahteraan masyarakat melalui peningkatan, pelayanan, pemberdayaan, dan peran serta masyarakat, serta peningkatan daya saing daerah dengan memperhatikan prinsip demokrasi, dalam sistem Negara Kesatuan Republik Indonesia."

Dalam Undang-Undang Nomor 23 tahun 2014 tentang Pemerintahan Daerah, pemilihan kepala daerah tidak lagi dipilih melalui sistem perwakilan oleh DPRD, namun dipilih secara langsung oleh rakyat. Ini berarti pemilihan kepala daerh secara langsung memberi peluang bagi rakyat untuk berpartisipasi dalam proses pengambilan keputusan yang sangat strategis dalam penyelenggaraan pemerintah daerah melalui pemilihan kepala daerah secara langsung. ${ }^{23}$

Menilik dari sejarahnya, pemilihan kepala daerah secara langsung pertama kali berlangsung pada tanggal 1 juni 2005, yang dilaksanakan di 207 Kabupaten/Kota dan 7 Provinsi. Tahun 2007 berlangsung Pilkada di 35 Kabupaten/Kota dan 6 Provinsi. Tahun

\footnotetext{
${ }^{21}$ Diakses dari https://jdih.jakarta.go.id/uploads/default/produkhukum/

22 Undang-Undang Nomor 23 Tahun 2014 tentang Pemerintahan Daerah

${ }^{23}$ Nopyandri, “Pemilihan Kepala Daerah Yang Demokrasi Dalam Perspektif UUD 1945” Jurnal/Ilmu Hukum Vol 2 No.2. Diakses Pada tanggal 27 Maret 2019
} 
2008 dilaksanakan 160 Pilkada di 13 Provinsi, 147 Kabupaten/Kota. Terakhir, pemilihan kepala daerah serentak kembali dilaksanakan pada tanggal 27 juni $2018 .^{24}$

Kabupaten Pasaman adalah salah satu daerah yang melaksanakan pemilihan kepala daerah secara serentak pada juni 2015. Pada pemilihan kepala daerah tersebut terdapat 2 pasangan calon yang memiliki etnis yang berbeda yaitu dari etnis Minangkabau dan etnis Mandailing. Kedua etnis tersebut merupakan etnis yang dominan di wilayah Kabupaten Pasaman. Banyak pihak yang menduga mengenai kedua pasangan calon tersebut mempengaruhi partisipasi masyarakat yang menurun, dan Pendidikan politik yang tidak dapat direalisasikan pada pemilihan umum kepala daerah terhitung dari 20102015.

Penelitian mengenai faktor-faktor yang mengakibatkan penurunan partisipasi masyarakat dan bagaimana fenomena dalam meyakinkan masyarakat tersebut untuk dapat berpartisipasi pada Pilkada 2015. Berdasarkan penelitian yang telah dilakukan oleh peneliti di lapangan dengan beberapa informan yang berperan dalam penyelenggaraan pemilihan umum kepala daerah, seperti tim sukses sekaligus anggota partai pengusung, $\mathrm{Kpu}$, dan kedua tokoh dari masyarakat etnis Minangkabau dan masyarakat etnis Mandailing.

Konsep dari Self Efficacy dapat digunakan oleh semua kalangan baik itu masyarakat sipil, pemerintahan, maupun masyarakat yang bekerja di bidang swasta. Pada bagian ini peneliti menggunakan konsep Efikasi Politik sebagai bagian dari Self Efficacy yang mana dapat dilihat dari Self Efficacy masyarakat yang ada di Kabupaten Pasaman terhadap Fenomena yang terjadi Pada saat Pilkada 2015.

Pada hakikatnya efikasi harus dipunyai setiap masyarakat atau orang yang terkait di dalam politik maupun pada setiap orang yang terikat dalam organisasi. Hal ini sering kali kita jumpai pada pemilu dalam bernegara atau dalam organisasi di pemerintahan (Birokrasi). Pada dasar nya pemilu sangat mempengaruhi pada pengaruh efikasi pada tingkat partisipasi masyarakat. ${ }^{25}$

Faktor-faktor yang mengakibat kan partisipasi masyarakat turun pada pelaksanaan pemilihan umum kepala daerah tahun 2015 di Kabupaten Pasaman terhitung dari pemilihan umum kepala daerah 2010 dan pemilihan umum kepala daerah 2015 dapat diteliti dari konsep Self Efficacy masyarakat terhadap penurunan partisipasi masyarakat yang ada di Kabupaten Pasaman.

Turunnya partisipasi masyarakat di Kabupaten Pasaman dari Pilkada 2010 ke 2015 peneliti melihat Self Efficacy terjadi karena beberapa faktor dari masyarakat di

243 Riwayat Pilkada di Indonesia, https://nasional.kompas.com/read/2018/06/27/06000041/riwayat pilkada-di-indonesia?page=1, diakses tanggal 17 april 2019.

${ }^{25}$ Op.Cit., Asmarani, Fadilah. "Hubungan antara efikasi diri dengan culture shock pada mahasiswa alumni non pesantren di Ma’had Sunan Ampel Al-Aly Universitas Islam Negeri Maulana Malik Ibrahim Malang” 2017. Hlm. 15 
Kabupaten Pasaman. Menurut Campbell terkait dengan Self Efficacy bahwa ada 2 faktor yang mempengaruhi Self Efficacy masyarakat yaitu faktor internal dan faktor eksternal. Faktor internal merupakan keyakinan tentang kompetensi seseorang untuk memahami dan berpartisipasi secara efektif dalam berpolitik. Sedangkan eksternal mencerminkan persepsi warga tentang sejauh mana pemerintah dan kelembagaan terhadap kebutuhan dan tuntutan. ${ }^{26}$ Pada terlihat pada fenomena Self Efficacy yang terjadi pada kontestasi Pilkada 2015 dilakukan. Imbas dari Self Efficacy masyarakat yang terlibat dalam Pilkada 2015 adalah pada masyarakat yang tidak memahami tentang Pilkada. Fenomena tersebut terjadi diawali pada dimensi pertama Faktor Internal

\section{Faktor Internal yang mengakibatkan partisipasi masyarakat di Kabupaten Pasaman menurun pada PIlkada 2015}

Menurut Sylvester efikasi politik internal merupakan keyakinan bahwa individu cukup kompeten untuk membuat perubahan dalam keputusan politik. efikasi politik internal lebih dipengaruhi oleh persepsi yang dimiliki seseorang mengenai kemampuan dirinya. ${ }^{27}$

Fenomena Self Efficacy masyarakat yang mengakibatkan turunnya partisipasi pada saat pelaksanaan Pilkada 2015 di Kabupaten Pasaman. Kedua Paslon yang akan naik menjadi calon Bupati di Kabupaten Pasaman memiliki suku yang berbeda. Menariknya kedua suku yang dimiliki oleh masing-masing kandidat merupakan suku yang mendominasi di wilayah Kabupaten Pasaman yaitu suku minang dan suku Mandailing.

Tidak ada pengaruh Self Efficacy masyarakat yang diakibatkan oleh perbedaan suku yang dimiliki oleh kedua Paslon yang mendominasi di wilayah Kabupaten Pasaman pada Pilkada 2015 yaitu Yusuf Lubis dari suku Mandailing dan Benny Utama dari Suku Minang. Penurunan partisipasi masyarakat di Kabupaten Pasaman dipengaruhi oleh nilai-nilai yang telah ditanamkan dalam diri mereka bahwa tidak ada gunanya untuk ikut berpartisipasi dalam pelaksanaan Pilkada.

Tanpa rasa efikasi politik internal, masyarakat pemilih kemungkinan akan menjadi apatis, acuh tak acuh terhadap proses politik yang terjadi. Keengganan itu kemudian akan membuat masyarakat memilih menjadi golongan putih. Partisipasi seseorang dalam bidang sosial dan politik merupakan bentuk tingkah laku sosial yang dipengaruhi oleh nilai-nilai yang dianutnya. Nilai digunakan untuk merepresentasikan tujuan-tujuan secara mental dan disampaikan melalui interaksi sosial.

Mereka menganggap bahwa tidak ada jaminan bagi mereka jika ikut serta berpartisipasi. Keadaan di wilayah Kabupaten Pasaman memang masih tradisional dan

\footnotetext{
${ }^{26}$ Restiani Fauzie, “Adaptasi dan Validasi skala Political Trust dan Political Efficacy”. Jurnal Psikologi dan Pendidikan Indonesia.Jakarta Vol.3 No. 4 Hlm 304

${ }^{27}$ Andri Nurcahya Dkk. "Perbedaan Efikasi Politik Ditinjau dari Kepribadian Introversi dan Ekstroversi Dewan Perwakilan Mahasiswa” Jurnal Psikologi terapan. Vol.7 No.22 2017
} 
penduduk di suatu wilayah tersebut masih kental dengan budaya dan Nilai-nilai yang telah ditanamnya. Sehingga penanaman nilai-nilai untuk ikut berpartisipasi pada saat pelaksanaan Pilkada tidak tersampaikan dengan baik. Bukan hanya dilihat pada faktor internal yang mengakibatkan penurunan partisipasi masyarakat di Kabupaten Pasaman.

\section{Faktor Eksternal yang Mengakibatkan Penurunan Partisipasi Masyarakat di Kabupaten Pasaman Pada Pilkada 2015}

Menurut Schwartz Faktor eksternal terkait dengan situasi atau lingkungan politik yang dibangun oleh Negara. Efikasi politik eksternal mengacu kepada rasa percaya akan lembaga atau pelaku politik. Tingkat efikasi politik internal lebih tinggi dari eksternal, tidak berarti bahwa mereka percaya pada lembaga politik. Persentase efikasi politik internal dan eksternal hampir mendekati $50 \%$ atau hampir seimbang. Artinya mereka juga bisa percaya atau tidak akan lembaga atau pelaku politik. ${ }^{28}$

Faktor Eksternal Pemerintahan Kabupaten Pasaman masih belum maksimal dalam melaksanakan program kerja yang tujuannya mendapatkan kepercayaan masyarakat khusus nya dalam partisipasi politik. Dalam pemerataan wilayah pemerintahan pada masa Yusuf Lubis tidak dapat dinikmati oleh semua kalangan masyarakat di Kabupaten Pasaman. Terlihat pada masyarakat yang memiliki suku yang sama dengan Yusuf Lubis kecewa dengan program kerja yang dijalankan pada masa pemerintahan Yusuf Lubis.

Hal tersebut disebabkan juga salah satunya pemerintah Kabupaten Pasaman tidak berhasil menekan biaya pendidikan. Dimana Pendidikan bagi masyarakat di Kabupaten Pasaman merupakan hal yang sangat penting, namun Pendidikan tersebut tidak semua masyarakat yang merasakannya. Hal tersebut mengakibatkan masyarakat kecewa dan kehilangan kepercayaan pada pemerintahan pada masa Yusuf Lubis. Kehilangan kepercayaan masyarakat dirasakan oleh pemerintahan pada saat Pelaksanaan Pilkada 2015, yang merupakan penurunan partisipasi masyarakat di Kabupaten Pasaman.

\section{KESIMPULAN}

Setelah menelaah panjang lebar melalui kajian lapangan (research) pada penelitian ini, maka dapat ditarik kesimpulan bahwa fenomena Self Efficacy Masyarakat yang mengakibatkan penurunan partisipasi masyarakat pada Pilkada 2015 di Kabupaten Pasaman disebabkan karena 2 faktor yaitu faktor internal dan faktor eksternal.

Tidak ada pengaruh Self Efficacy masyarakat yang diakibatkan oleh perbedaan suku yang dimiliki oleh kedua Paslon yang mendominasi di wilayah Kabupaten Pasaman pada Pilkada 2015 yaitu Yusuf Lubis dari suku Mandailing dan Benny Utama dari Suku

\footnotetext{
${ }^{28}$ Andi Nurcahya, et.al "Perbedaan Efikasi Politik Ditinjau dari Kepribadian Ekstraversi Pada Dewan Perwakilan Mahasiswa", Jurnal Psikologi Teori dan Terapan, Vol.7 (2) 2017, Hlm.80
} 
Minang. Penurunan partisipasi masyarakat di Kabupaten Pasaman dipengaruhi oleh nilainilai yang telah ditanamkan dalam diri mereka bahwa tidak ada gunanya untuk ikut berpartisipasi dalam pelaksanaan Pilkada.

Tanpa rasa efikasi politik internal, masyarakat pemilih kemungkinan akan menjadi apatis, acuh tak acuh terhadap proses politik yang terjadi. Keengganan itu kemudian akan membuat masyarakat memilih menjadi golongan putih. Partisipasi seseorang dalam bidang sosial dan politik merupakan bentuk tingkah laku sosial yang dipengaruhi oleh nilai-nilai yang dianutnya. Nilai digunakan untuk merepresentasikan tujuan-tujuan secara mental dan disampaikan melalui interaksi sosial.

Mereka menganggap bahwa tidak ada jaminan bagi mereka jika ikut serta berpartisipasi. Keadaan di wilayah Kabupaten Pasaman memang masih tradisional dan penduduk di suatu wilayah tersebut masih kental dengan budaya dan Nilai-nilai yang telah ditanamnya. Sehingga penanaman nilai-nilai untuk ikut berpartisipasi pada saat pelaksanaan Pilkada tidak tersampaikan dengan baik. Bukan hanya dilihat pada faktor internal yang mengakibatkan penurunan partisipasi masyarakat di Kabupaten Pasaman.

Sedangkan Faktor Eksternal Pemerintahan Kabupaten Pasaman masih belum maksimal dalam melaksanakan program kerja yang tujuannya mendapatkan kepercayaan masyarakat khusus nya dalam partisipasi politik. Dalam pemerataan wilayah pemerintahan pada masa Yusuf Lubis tidak dapat dinikmati oleh semua kalangan masyarakat di Kabupaten Pasaman. Terlihat pada masyarakat yang memiliki suku yang sama dengan Yusuf Lubis kecewa dengan program kerja yang dijalankan pada masa pemerintahan Yusuf Lubis.

Hal tersebut disebabkan juga salah satunya pemerintah Kabupaten Pasaman tidak berhasil menekan biaya pendidikan. Dimana Pendidikan bagi masyarakat di Kabupaten Pasaman merupakan hal yang sangat penting, namun Pendidikan tersebut tidak semua masyarakat yang merasakannya. Hal tersebut mengakibatkan masyarakat kecewa dan kehilangan kepercayaan pada pemerintahan pada masa Yusuf Lubis. Kehilangan kepercayaan masyarakat dirasakan oleh pemerintahan pada saat Pelaksanaan Pilkada 2015, yang merupakan penurunan partisipasi masyarakat di Kabupaten Pasaman.

\section{DAFTAR PUSTAKA}

Afrizal, 2014, “Metode Penelitian Kualitatif”. Jakarta: raja grafindo persada.

Amran. "Mandailing Phonologi Minangkabau di Perbatasan Pasaman Timur dan Tapanuli Selatan”. Jurnal Humanities and Social Science. 2005 Hal 1

Asmarani, Fadhilah. "Hubungan Antara Efikasi Diri Dengan Culture Shock Pada Mahasiswa Alumni Non Pesantren”. Mad'ah Sunan Ampel Al-Aly Universitas Islam Negeri Maulana Malik Ibrahim. Malang. 2017. Hal 13

Budiarjo, Miriam. 2001. “Dasar-Dasar Ilmu Politik”. Jakarta. Gramedia Pustaka Utama Bungin, Burhan. 2007. "Penelitian Kualitatif”. Jakarta. PT. Raja Grafindo Persada. 
Novandri. "Pemilihan Kepala Daerah Yang Demokrasi Dalam Perspektif UUD 1945". Jurnal/Ilmu Hukum Vol 2 No.2. Diakses Pada tanggal 27 Maret 2019

Nur cahya Andi, et.al "Perbedaan Efikasi Politik Ditinjau dari Kepribadian Ekstrovert Pada Dewan Perwakilan Mahasiswa”, Jurnal Psikologi Teori dan Terapan, Vol.7 (2) 2017, Hlm.77

Oktaverina, Isnaini dan Nashori, H. Fuad. "Efektivitas Pelatihan Efikasi Diri Dalam Meningkatkan Motivasi belajar". Talenta Vol.1(1): 1-14

Rahmayati, T. Elvira. "Hubungan Efikasi Akademik dan Dukungan Sosial dengan Penyesuaian Diri”. Jurnal ISSN: 2085-6601. Hal 43-49

Rasmussen Dan Norgaard. "Kapan Dan Mengapa Hal Pendidikan? Motivasi Dan Sumber Daya Efek Dalam Efikasi Politik”. European Journal of Research Politik, 57, 24-46. 2018

Rustika, I Made. "Efikasi Diri: Tinjauan Teori Albert Bandura" Fakultas Psikologi Universitas Gadjah Mada, 2012 Vol.20 Hal 18

Saepudin, Asep. Dkk. “Efektivitas Pelatihan dan Efikasi Diri”. Jurnal Mimbar. Vol.31(1): 93-102

Suseno, Miftahun Ni'mah. "Pengaruh Pelatihan Komunikasi Interpersonal Terhadap Efikasi Diri Sebagai Pelatihan Pada Mahasiswa”. Jakarta Pusat: Kementerian Agama Republik Indonesia Tahun 2012. Hal 24

Yin, Robert K. 2003, "Studi Kasus (Desain dan Metode". Jakarta: PT Raja Grafindo Persada 